Article

\title{
Red Lentil (Lens culinaris) Extract as a Novel Natural Coagulant for Turbidity Reduction: An Evaluation, Characterization and Performance Optimization Study
}

\author{
Siong-Chin Chua ${ }^{1,2} \oplus$, Marlinda Abdul Malek ${ }^{3}$, Fai-Kait Chong ${ }^{4}$, Wawan Sujarwo ${ }^{5}$ \\ and Yeek-Chia Ho 1,2,*(D) \\ 1 Civil and Environmental Engineering Department, Universiti Teknologi PETRONAS, Seri Iskandar, \\ Perak Darul Ridzuan 32610, Malaysia \\ 2 Centre for Urban Resource Sustainability, Institute of Self-Sustainable Building, Universiti Teknologi \\ PETRONAS, Seri Iskandar, Perak Darul Ridzuan 32610, Malaysia \\ 3 Institute of Sustainable Energy (ISE), Universiti Tenaga Nasional, Selangor 43000, Malaysia \\ 4 Fundamental and Applied Sciences Department, Universiti Teknologi PETRONAS, Seri Iskandar, \\ Perak Darul Ridzuan 32610, Malaysia \\ 5 Bali Botanical Gardens, Indonesian Institute of Sciences (LIPI), Candikuning Baturiti, \\ Tabanan Bali 82191, Indonesia \\ * Correspondence: yeekchia.ho@utp.edu.my; Tel.: +605-3687319
}

Received: 30 May 2019; Accepted: 8 July 2019; Published: 14 August 2019

\begin{abstract}
Increasing awareness on the detrimental effects of inorganic chemical coagulants and sustainable treatment have paved the way to develop environmentally-benign natural coagulants for water and wastewater treatment. In this research, brown, green, and red lentil (Lens culinaris) extracts have been evaluated as a natural coagulant for the turbidity reduction. The physicochemical characteristics properties of lentil extract were evaluated through field emission scanning electron microscopy (FESEM), Fourier-transform infrared spectroscopy (FTIR), zeta potential analysis, and energy-dispersive X-ray (EDX) analysis. Red lentil extract was found to be an anionic polymer with hydroxyl and carboxyl functional groups. The effects of three major operating parameters, $\mathrm{pH}$, the concentration of coagulant, and settling time, were studied and optimized through response surface methodology (RSM) using the Box-Behnken Design (BBD). The red lentil extract as coagulant was outperformed alum in acidic wastewater treatment, which achieved up to $98.87 \%$ turbidity removal with an optimum concentration of $26.3 \mathrm{mg} / \mathrm{L}$ in $3 \mathrm{~min}$. Besides, the red lentil extract as coagulant reduced $29.42 \%$ of material cost, generated $15.6 \%$ lower amount of sludge and produced flocs with better settling characteristic (SVI: 7.39) as compared to alum. Based on the experimental observation and characterization study, absorption and bridging mechanisms were proposed for red lentil extract as the coagulant in turbidity reduction.
\end{abstract}

Keywords: natural coagulant; lentil extracts; response surface methodology; polysaccharide; coagulation and flocculation; water and wastewater treatment

\section{Introduction}

Over the years, the coagulation-flocculation process remains as a common and essential process for water and wastewater treatment due to its simple and cost-effectiveness properties. Among all the available coagulants, inorganic coagulant, especially aluminum sulphate (alum) and iron (III) chloride were widely used in the coagulation-flocculation process. 
However, the inorganic coagulant used has raised controversial issues due to its toxicity which could potentially be hazardous to human health. Increasing studies have reported that the residual aluminum (from alum) retained in the water after the treatment may induce Alzheimer's disease [1,2]. Apart from potential health impacts, the use of inorganic coagulant produces a large volume of aluminum-based sludges that caused ecotoxicological impact on the living organism. Some countries, e.g., Malaysia, France, and Germany, have started to categorize these aluminum sludges as schedule wastes which require special treatment and handling methods. Moreover, certain developing countries cannot afford the costs of the imported chemicals for the coagulation-flocculation treatment.

These limitations have led to an increasing demand for alternative natural coagulants. Natural coagulants are generally extracted from plants, animals, or microorganisms. Natural coagulants i.e., Moringa olerifera, chitosan, tannins, okra, and Nirmali seeds, have been proven as effective coagulants for turbidity reduction [2]. They are found to be non-toxic, low cost, locally available, environmentally friendly, and readily implementable [1] which augers great potential as an alternative for the current used inorganic coagulant. Lentil (Lens culinaris) is a grain legume belonging to leguminosae family and grown annually on various type of soils including sand and clay. It was originated from the Near East and had been spreading to the Mediterranean, Asia, and North America since the 1900s [3]. In 2010, the production of the lentils was up to 4.58 million metric tons produced in more than 48 countries worldwide [4]. Generally, lentils can be divided into three main types: brown, green, and red lentils. According to Canada [5], red lentils occupied $70 \%$ of worldwide lentil production, followed by green lentils $(25 \%)$, and lastly brown and other lentils (5\%). Lentils contain approximately $69 \%$ carbohydrates, of which the majority are in the starch form.

Lentil extract was first studied by Schulz and Okun [6] as the coagulant aid in water treatment, and it helped to reduce the alum concentration up to $40 \%-50 \%$. The second study was conducted by Ordaz-Díaz et al. [7] where the lentil extract was used as coagulant aid in pulp and paper wastewater. The finding revealed that the lentil extract helps to reduce up to $29 \%$ of coagulant concentration. However, research areas utilizing lentil extract alone as natural coagulant specifically in turbidity reduction remained scarce. To better understand the feasibility of lentil extract as a coagulant for turbidity reduction, an improved characterization study on different lentil extracts, and their efficiency in turbidity reduction is needed. In view of all the aforementioned aspects, this study consists of few aspects which included (1) evaluation of the efficiency of different lentil extracts, (2) characterization of the brown, green and red lentils extracts, (3) optimization the selected lentil extract as coagulant, (4) evaluation of the sludge produced, and (5) economic feasibility study on lentil extract as coagulant. Moreover, response surface methodology (RSM) was adopted to study the influence of operating parameters $(\mathrm{pH}$, concentration of coagulant, and settling time) on the turbidity reduction by the lentil extract and to determine their respective optimum conditions. Alum was used as a comparative coagulant in this study.

\section{Materials and Methods}

\subsection{Materials}

The brown, green and red lentils used in this study were purchased from the local market. Analytical-reagent-grade of aluminum sulphate $98 \%\left(\mathrm{Al}_{2}\left(\mathrm{SO}_{4}\right)_{3}\right)$, kaolin powder, $1 \mathrm{M}$ of sodium hydroxide $(\mathrm{NaOH})$, and $1 \mathrm{M}$ of hydrochloride acid $(\mathrm{HCl})$ were purchased from Sigma Aldrich (Malaysia) and used without further purification. 


\subsection{Methods}

\subsubsection{Preparation of Lentil Extracts}

The fresh brown, green, and red lentils were washed completely with distilled water to remove the impurities, i.e., dirt and dust, and oven-dried at $45^{\circ} \mathrm{C}$ for $2 \mathrm{~h}$. After drying, the lentils were ground into a fine powder that passed through a $150 \mu \mathrm{m}$-mesh sieve.

The ready lentil powder was then mixed with the distilled water at the lentil to water ratio of 1:15 and heated to $80^{\circ} \mathrm{C}$ for $1 \mathrm{~h}$ to extract the active compound from the lentil.

The solution was cooled down to the room temperature centrifuged at $3500 \mathrm{rpm}$ (revolutions per minute) for $10 \mathrm{~min}$ to remove all the impurities. The solution was oven-dried to obtain dry lentil extract. Prior to the jar testing, the coagulant solution with $3 \mathrm{~g} / \mathrm{L}$ concentration was prepared by adding $300 \mathrm{mg}$ of lentil extract into $100 \mathrm{~mL}$ of distilled water. The mixture was then agitated at $80^{\circ} \mathrm{C}$ for $1 \mathrm{~h}$ just before coagulation.

\subsubsection{Preparation of Model Turbid Water}

The stock solution of the model turbid water was prepared by dissolving $10 \mathrm{~g}$ of kaolin powder into $2 \mathrm{~L}$ of tap water. The kaolin suspension was agitated for $2 \mathrm{~h}$ and allowed to settle down for at least $24 \mathrm{~h}$ for complete hydration. The supernatant of the suspension was collected and used as a stock solution. The stock solution was diluted to obtained turbid water with 800 Nephelometric Turbidity Units (NTU). The initial $\mathrm{pH}$ of the stock solution was $6.8 \pm 0.1$. For $\mathrm{pH}$ adjustment, $1 \mathrm{M}$ of $\mathrm{NaOH}$ and $\mathrm{HCl}$ were used.

\subsubsection{Analytical Method}

The $\mathrm{pH}$ of the water was measured using $\mathrm{HACH} \mathrm{HQ} 11 \mathrm{~d} \mathrm{pH}$ meter while the turbidity of the water sample in NTU was measured using $\mathrm{HACH} 2100 \mathrm{Q}$ turbidity meter. The functional group of the lentils were analyzed by Fourier-transform infrared spectroscopy (FTIR), and the adsorption band was recorded at characteristics wave numbers at the range of $4000 \mathrm{~cm}^{-1}-400 \mathrm{~cm}^{-1}$. Field emission scanning electron microscopy equipped with energy dispersive analysis of X-ray (Perkin Elmer Spectrum) was used to determine elemental composition and the morphological properties of the lentil. The zeta potential of the lentil extracts $(1 \mathrm{mg} / \mathrm{mL}$ in $0.1 \mathrm{M}$ of sodium chloride at $\mathrm{pH} 7)$ were analyzed through Malvern Zetasizer Nano (ZSP) at $25^{\circ} \mathrm{C}$ with $173^{\circ}$ measurement angle. Wet flocs were observed through the microscope (LEICA DM LB2).

\subsubsection{Assay of Turbidity Reduction}

Turbidity reduction of the turbid water was evaluated through the jar test using VELP Scientifica srl-JLT6 flocculator, which supports 6 units of beakers. Kaolin suspensions were filled into the breaker and coagulants were added accordingly. Then, suspensions were agitated at the intensity of $150 \mathrm{rpm}$ for one minute, followed by slow mixing at $30 \mathrm{rpm}$ for $20 \mathrm{~min}$ for growth of flocs. The suspensions were left undisturbed (1-20 $\mathrm{min}$ ) and the supernatants were collected using a $10 \mathrm{~mL}$ syringe at the scheduled time for final turbidity measurement. The turbidity reduction efficiency was calculated by using Equation (1). Each result obtained and shown was the average value of triplicate measurements. All the jar test experiments were conducted at room temperature $\left(22^{\circ} \mathrm{C} \pm 2{ }^{\circ} \mathrm{C}\right)$.

$$
\text { Turbidity Reduction }(\%)=\frac{\text { Initial Turbidity }- \text { Final Turbidity }}{\text { Initial Turbidity }} \times 100 \%
$$

\subsubsection{Sludge Volume and Sludge Volume Index (SVI) Measurement}

The volume of the sludge produced for this study was measured using Imhoff cones through volumetric method [8]. After the jar test experiment, the treated water with the settled flocs was transferred to a $1 \mathrm{~L}$ Imhoff cone. The sludge production volume in $\mathrm{mL}$ was measured after $1 \mathrm{~h}$ of 
settling time. Besides, Sludge Volume Index (SVI) was determined using Standard Methods for the Examination of Water and Wastewater to quantify the settling characteristic of the settled flocs. The SVI was calculated using Equation (2) [9].

$$
\operatorname{SVI}\left(\frac{\mathrm{mL}}{\mathrm{g}}\right)=\frac{\text { Settled sludge volume after } 30 \mathrm{mins}\left(\frac{\mathrm{mL}}{\mathrm{L}}\right) \times 1000}{\text { Total suspended solid }\left(\frac{\mathrm{mg}}{\mathrm{L}}\right)}
$$

\subsubsection{Experiment Design}

The coagulating and flocculating ability of brown, green, and red lentil extracts were first evaluated through the jar test by variation of lentil extracts concentration $(0 \mathrm{mg} / \mathrm{L}, 5 \mathrm{mg} / \mathrm{L}, 10 \mathrm{mg} / \mathrm{L}, 15 \mathrm{mg} / \mathrm{L}$, $20 \mathrm{mg} / \mathrm{L}, 25 \mathrm{mg} / \mathrm{L}$, and $30 \mathrm{mg} / \mathrm{L}$ ) and the $\mathrm{pH}$ and settling time was fixed at 4 and 20 min respectively. The operating parameters $(\mathrm{pH}$, concentration of coagulant and settling time) of the lentil extracts with best turbidity reduction efficiency were then further optimized to investigate its feasibility in turbidity reduction.

A statistical method, response surface methodology (RSM) was used for optimization [10]. RSM helps to quantify the relationship between the designed responds and minimizes the number of experiment runs. In the present study, the three-level Box-Behnken Design (BBD), one of the widely used design of RSM, was adopted to investigate and optimize three independent operating parameters ( $\mathrm{pH}$, concentration of lentil extract, concentration of alum, and settling time) affecting the turbidity reduction. The operating parameters and their respective range were ascertained through the results of preliminary experiments. The levels of the three retained operating parameters are coded as low $(-1)$, central point $(0)$, and high $(+1)$ as illustrated in Table 1 . Turbidity reduction efficiency in term of percentage was chosen as the dependent output variable. A total of 15 experiment runs for 3 operating parameters, including three replications at the center point were designed by the Design Expert software (version 10.0.1, Stat-Ease, Inc., Minneapolis, MN, USA). To avoid the effect of unexplained variability in the observed response due to the extraneous variables, all the experiment runs were carried out in random order.

$$
\mathrm{Y}=b_{o}+\sum_{i=1}^{k} b_{i} X_{i}+\sum_{i=1}^{k} b_{i i} X_{i}^{2}+\sum_{i>j}^{k} \cdot \sum_{j}^{k} b_{i j} X_{i} X_{j}+e
$$

where $\mathrm{Y}$ is the predicted response; $X_{i}$ and $X_{j}$ are the coded level of the independent variables (operating parameters), $b_{o}$ is a constant coefficient; $b_{i}, b_{i i}, b_{i j}$ are the coefficients of the linear, interaction, and quadratic terms, respectively, $k$ is the number of independent variables; and $e$ is the random error.

Table 1. Experimental domain of the Box-Behnken (BBD) design for using lentil or alum as coagulant.

\begin{tabular}{cccccc}
\hline \multirow{2}{*}{ Operating Parameters } & \multirow{2}{*}{ Units } & Coded Symbols & \multicolumn{3}{c}{ Range and Level } \\
\cline { 4 - 6 } & & & $\mathbf{- 1}$ & $\mathbf{0}$ & $\mathbf{+ 1}$ \\
\hline Lentil as coagulant & & $\mathrm{X}_{1}$ & 4 & 7 & 10 \\
$\mathrm{pH}$ & $\mathrm{X}$ & 0.1 & 15.05 & 30 \\
Concentration of lentil & $\mathrm{mg} / \mathrm{L}$ & $\mathrm{X}_{3}$ & 1 & 10.5 & 20 \\
Settling time & minute(s) & & & & \\
Alum as coagulant & & $\mathrm{Y}_{1}$ & 4 & 7 & 10 \\
pH & $\mathrm{mg} / \mathrm{L}$ & $\mathrm{Y}_{2}$ & 0.1 & 15.05 & 30 \\
Concentration of $\left(\mathrm{Al}^{3+}\right)$ & minute(s) & $\mathrm{Y}_{3}$ & 1 & 10.5 & 20 \\
Settling time & & & &
\end{tabular}




\subsubsection{Verification of the Designed Model}

Optimum conditions of the operating parameters were obtained using the predictive equation of the RSM through design expert software. To validate the model, validation experiments were carried out in triplicate to compare the predicted value by the designed model with the experimental value.

\section{Results and Discussion}

\subsection{Physicochemical Characteristics of Brown, Green, and Red Lentils}

\subsubsection{Surface Morphology of the Lentils}

The dry brown, green, and red lentil extracts were characterized according to their surface morphologies, surface zeta potential, and element contents to establish a thorough understanding on the feasibility of different lentils as a natural coagulant for turbidity reduction. The surface morphologies of the lentils were observed under the Field Emission Scanning Electron Microscopy (FESEM) and their respective images were compared as shown in Figure 1. The FESEM images of dried brown, green, and red lentil extracts reveal the irregular shape distribution structure which similar to the structure of the cactus bio-coagulant reported by Choudhary et al. [11]. Interestingly, all three lentil extracts exhibited same rough surface with pores and obvious surface abrasions. Zheng et al. [12] and J. Ma et al. [13] claimed the presence of pores at the surface of biopolymer reveal the good flocculating properties of the material as it aided in the particle adsorption and bringing processes. Comparing at magnification of 1000 times, red lentil extract granules have the largest particle size, followed by green lentil, while brown lentil extract granules have the smallest average particle size.

\subsubsection{Elemental Compositions of the Lentils}

The elemental compositions of brown, green and red lentils were determined by EDX analysis and the results are tabulated in Table 2. All three lentil extracts were highly carbonaceous materials which mainly made up of carbon and oxygen. The elemental composition results were found to be in close agreement with the natural coagulant reported by R. Ahmad and Haseeb [14] and Agunbiade et al. [15] where carbon and oxygen were the major components for natural coagulant. Some inorganic elements, i.e., calcium (Ca) was detected in trace amount for red lentil extract and potassium (K) for red and brown lentil extracts. The presence of calcium element in red lentil extract might aids in the coagulation process due to it positively charge in nature.

Table 2. Energy-dispersive X-ray spectroscopy analysis of the lentils.

\begin{tabular}{ccccccc}
\hline \multirow{2}{*}{ Elements } & \multicolumn{3}{c}{ Weight (\%) } & \multicolumn{3}{c}{ Atomic (\%) } \\
\cline { 2 - 7 } & Brown Lentil & Green Lentil & Red Lentil & Brown Lentil & Green Lentil & Red Lentil \\
\hline C & 59.68 & 54.69 & 53.12 & 66.50 & 61.72 & 60.91 \\
O & 39.86 & 45.08 & 44.33 & 33.34 & 38.20 & 38.16 \\
K & 0.39 & 0.23 & 1.45 & 0.13 & 0.08 & 0.51 \\
P & 0.06 & 0.00 & 0.32 & 0.03 & 0.00 & 0.14 \\
Ca & 0.00 & 0.00 & 0.78 & 0.00 & 0.00 & 0.27 \\
\hline
\end{tabular}

\subsubsection{Zeta Potential of the Lentils}

Zeta potential analysis was carried out to determine the surface charge of lentil extracts as it significantly affects the application of the respective biopolymer. The triplicates zeta potential results of brown, green, and red lentils were $-3.74 \mathrm{mV},-2.91 \mathrm{mV}$, and $-5.91 \mathrm{mV}$, respectively, which revealed the anionic properties of the lentil extracts (Table 3). As the surface charge was negative, the primary governing mechanisms are postulated to be absorption and particle bridging. The detail coagulation-flocculation mechanism through lentil extract is discussed later in this paper. 
Table 3. Zeta potential of the lentil extracts.

\begin{tabular}{ccccc}
\hline \multirow{2}{*}{ Lentil } & \multicolumn{4}{c}{ Zeta Potential (mV) } \\
\cline { 2 - 5 } & $\mathbf{1}$ & $\mathbf{2}$ & $\mathbf{3}$ & Average \\
\hline Brown lentil & -3.58 & -4.06 & -3.58 & -3.74 \\
Green lentil & -3.58 & -2.81 & -2.34 & -2.91 \\
Red lentil & -6.77 & -5.17 & -5.79 & -5.91 \\
\hline
\end{tabular}

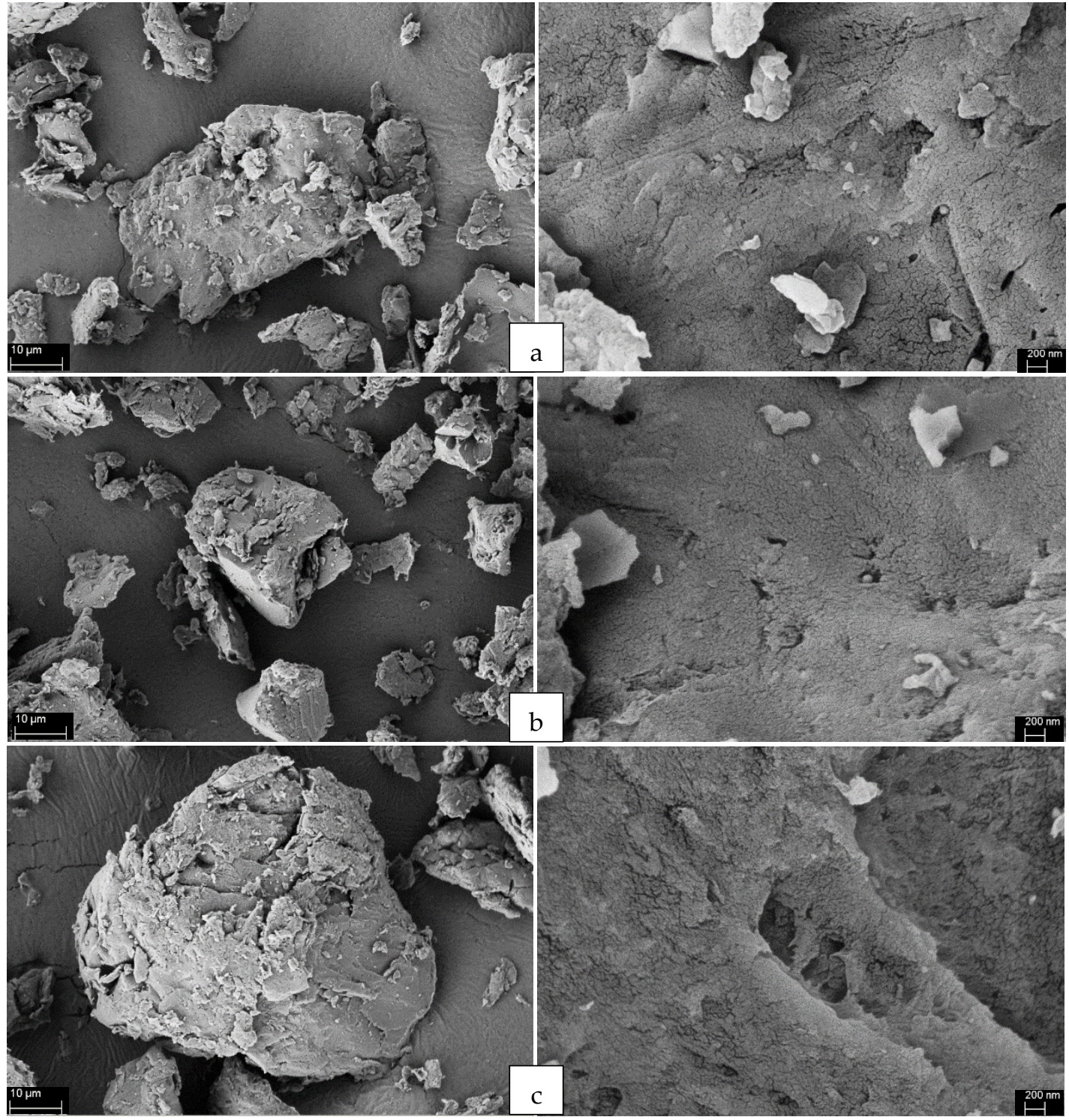

Figure 1. FESEM images of (a) brown lentil, (b) green lentil, and (c) red lentil at a magnification of $1000 \times$ (left) and 20,000× (right).

\subsubsection{Functional Groups of the Lentils}

FTIR analysis was conducted to study the functional groups present in the brown, green, and red lentils extracts, and the results are shown in Figure 2. The spectrum observed for all three lentils extracts were similar. The strong peak observed at 3400-3294 $\mathrm{cm}^{-1}$ was attribute to the $\mathrm{OH}$ functional group and the $\mathrm{O}-\mathrm{H}$ stretching of the polymeric compound [16]. Besides, the peak at 2929-2928 $\mathrm{cm}^{-1}$ was recognized as $\mathrm{C}-\mathrm{H}$ groups [17]. Both $\mathrm{O}-\mathrm{H}$ and $\mathrm{C}-\mathrm{H}$ functional groups could be attributed to the protein content found in the lentil extracts [18]. The characteristic peak of stretching of the 
carboxylic COO-double bond of deprotonated carboxylate functional groups was observed at around $1660-1657 \mathrm{~cm}^{-1}$ [19]. A band in the region around $1549-1540 \mathrm{~cm}^{-1}$ shows the presence of $\mathrm{C}=\mathrm{O}$ functional group. The peaks between $1000-1200 \mathrm{~cm}^{-1}$ were associated with the stretching of C-O in aromatic compounds of galactose, rhamnose, and galacturonic acid [20] and -OH of polysaccharide [19]. The presence of various of functional groups especially hydroxyl and carboxyl functional groups in lentil extract reveals its potential to adsorb a wide range of contaminant which could aids in the turbidity reduction.
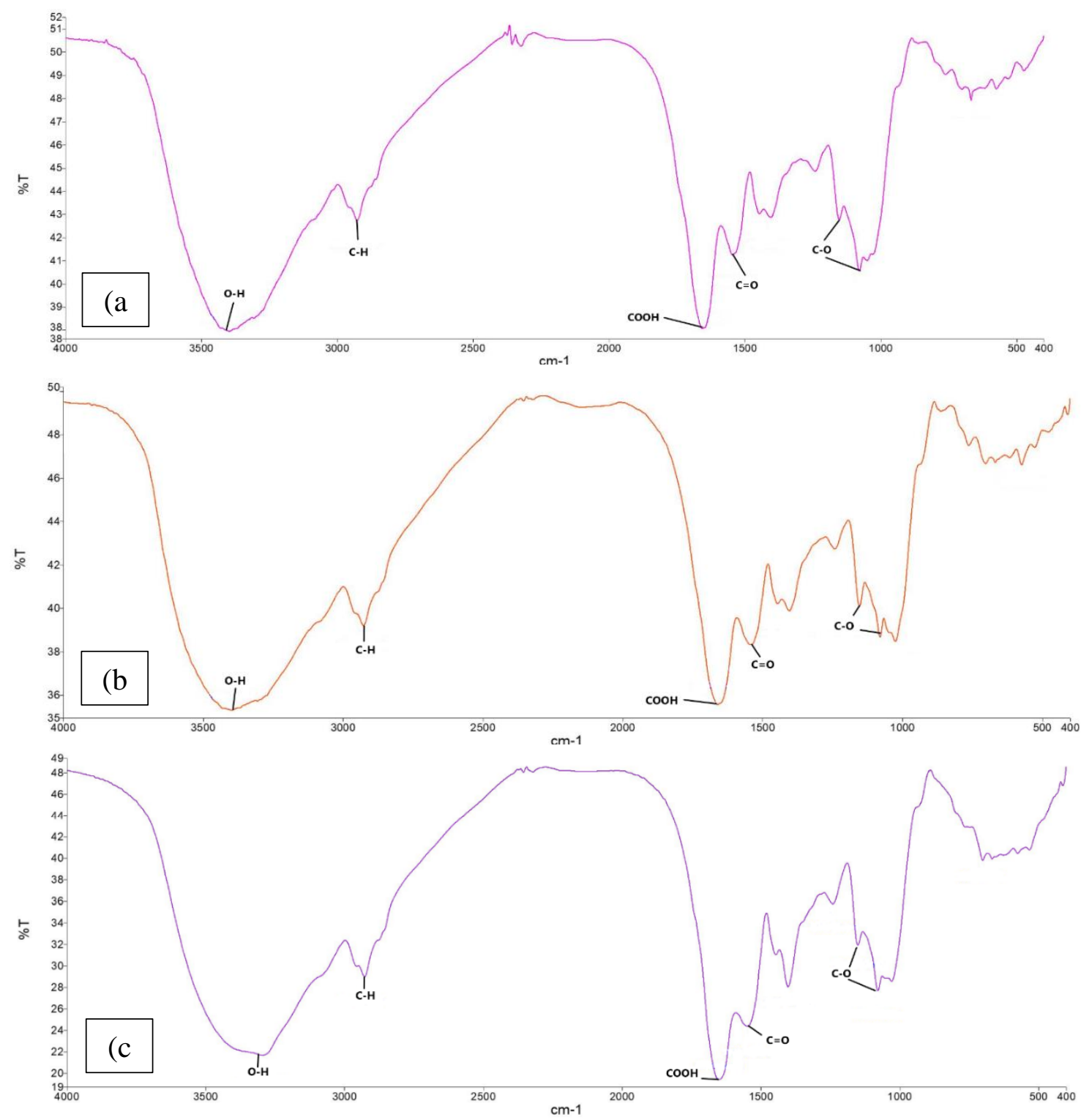

Figure 2. FTIR result of (a) red, (b) green, and (c) red lentil extract.

\subsection{Preliminary Study on the Coagulating Ability of Different Lentils}

The preliminary study on the coagulation ability brown, green and red lentil extracts were conducted through the jar test experiment at fixed initial $\mathrm{pH}$. Figure 3 shows the turbidity reduction value in percentage achieved by different lentil extracts. Amongst, red lentil extract outperformed brown and green lentil extracts, which exhibited the highest coagulation activities across all concentrations. The red lentil extract achieved a maximum of $93 \%$ reduction at the concentration range from $15-20 \mathrm{mg} / \mathrm{L}$. Contrastingly, brown and green lentil extracts only achieved maximum $83.8 \%$ and $83.1 \%$ of turbidity 
reduction, respectively at a higher concentration of $20-25 \mathrm{mg} / \mathrm{L}$. The high coagulation ability of red lentil extract was attributed to its high protein content as compared to other lentils. The protein content of red lentil was reported at $31.5 \pm 1.1 \%$ [21] while brown and green lentils were $24.83 \pm 0.02 \%$ [22] and $24.90 \%$ [23], accordingly. Besides, the total amylose content of red lentil was found to be highest (32.52\%), followed by green lentil (30.6\%-31.2\%), and brown lentil (28.6\%) [23]. Amylose was identified as an important element that helps in the bridging mechanism through projecting the polymer chain into surrounding to allow the absorption of particles onto the surface of the polymer chain [24]. Apart from the protein and amylose content, the EDX result (Table 2) explained the high coagulating ability of red lentil as calcium element that aids in coagulation and flocculation activities was found to present in the red lentil extract. As red lentil extract was found to have the best efficiency in turbidity reduction, it was further used as coagulant for optimization to investigate its feasibility in turbidity reduction.

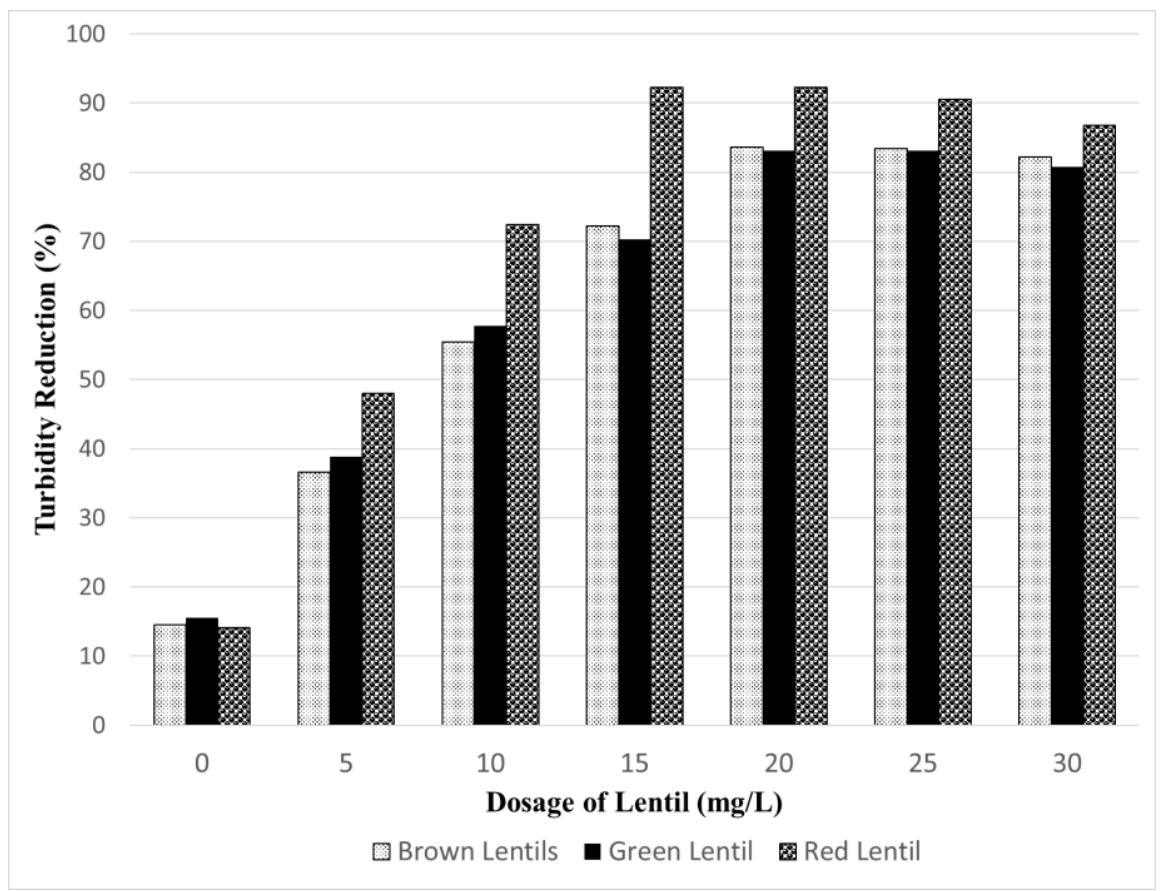

Figure 3. Turbidity reduction using brown, green and red lentil extracts as coagulant at $\mathrm{pH} 4$.

\subsection{Model Adequacy Checking}

Model adequacy checking is essential to ensure the designed model gives an accurate approximation to the real system and avoid poor or misleading results. $\mathrm{R}^{2}$, adjusted $\mathrm{R}^{2}$ and predicted $\mathrm{R}^{2}$ are important indicators used to evaluate the overall performance of the designed model. The $\mathrm{R}^{2}$ value close to 1 is desirable and the predicted $R^{2}$ is required to be in reasonable agreement (the different need to less than 0.2 ) with the adjusted $R^{2}$. The analysis of variance (ANOVA) of the designed models is tabulated in Table 4 . The $\mathrm{R}^{2}$ value of models when red lentil extract and alum used as coagulant were relatively high, 0.9996 and 0.9876 , respectively, which indicates that only $0.04 \%$ and $1.24 \%$ of total variation could not be explained by the model. $p$-value associated with the $95 \%$ confidence level was adopted to evaluate the model, operating parameters, and their interactions. The $p$-value of all designed models were $<0.0001$ and 0.0003 , respectively which found to be significant at $95 \%$ confidence level. Besides, the insignificant lack of fit of the model ( $p$-value: 0.0859 and 0.0998 ) indicate the success of the models to fits the data in the experimental domain. The adequate precision of all designed models (107.63 and 16.60) is above the desired value (4), proving that the designed models can be utilized for navigation of the design space by the BBD. This is also evident from the diagnostic plots (predicted vs. actual values) of turbidity reduction as illustrated in Figure 4. The model adequacy can be judged through the diagnostic plots, i.e., the predicted vs. actual values plot [25]. The actual values 
were distributed close to $y=x$ (approximately along a straight line), showing that the predicted value corresponds well with the measured value. This result, therefore, visualizes the good performance of the designed model and shows satisfactory agreement between the actual data and the data from the designed models. In view of all the aforementioned aspects, the overall second-order models for the turbidity reduction are proven to be significant and adequate for the optimization process.

Table 4. Analysis of variance (ANOVA) table.

\begin{tabular}{ccccc}
\hline Source & Sum of Squares & Mean Square & F Value & $p$-Value \\
\hline & Red lentil extract as coagulant & & \\
Model & 9388.94 & 1043.22 & 1317.57 & $<0.0001$ \\
pH $\left(X_{1}\right)$ & 4586.50 & 4586.50 & 5792.7 & $<0.0001$ \\
Concentration of lentil extract $\left(X_{2}\right)$ & 131.67 & 131.67 & 166.3 & $<0.0001$ \\
Settling Time $\left(X_{3}\right)$ & 177.84 & 177.84 & 224.61 & $<0.0001$ \\
$X_{1} X_{2}$ & 23.67 & 23.67 & 29.89 & 0.0028 \\
$X_{1} X_{3}$ & 64.63 & 64.63 & 81.63 & 0.0003 \\
$X_{2} X_{3}$ & 95.62 & 95.62 & 120.77 & 0.0001 \\
$X_{1}^{2}$ & 4136.59 & 4136.59 & 5224.46 & $<0.0001$ \\
$X_{2}^{2}$ & 49.26 & 49.26 & 62.21 & 0.0005 \\
$X_{3}^{2}$ & 1.45 & 1.45 & 1.84 & 0.2334 \\
Lack of Fit & 3.73 & 1.24 & 10.80 & 0.0859
\end{tabular}

R-squared $=0.9996$, adjusted R-squared $=0.9988$, adequate precision $=107.625$, predicted R-Squared $=0.99$

\begin{tabular}{ccccc}
\hline & Alum as coagulant & & \\
Model & $18,254.86$ & 2028.32 & 44.20 & 0.0003 \\
$\mathrm{pH}\left(Y_{1}\right)$ & 3105.94 & 3105.94 & 67.68 & 0.0004 \\
Concentration of alum $\left(Y_{2}\right)$ & 2925.60 & 2925.60 & 63.75 & 0.0005 \\
Settling Time $\left(Y_{3}\right)$ & 4828.49 & 4828.49 & 105.21 & 0.0002 \\
$Y_{1} Y_{2}$ & 1.01 & 1.01 & 0.02 & 0.8877 \\
$Y_{1} Y_{3}$ & 225.09 & 225.09 & 4.90 & 0.0776 \\
$Y_{2} Y_{3}$ & 758.31 & 758.31 & 16.52 & 0.0097 \\
$Y_{1}^{2}$ & 1343.25 & 1343.25 & 29.27 & 0.0029 \\
$Y_{2}^{2}$ & 1704.82 & 1704.82 & 37.15 & 0.0017 \\
$Y_{3}^{2}$ & 4232.44 & 4232.44 & 92.22 & 0.0002 \\
Lack of Fit & 213.94 & 71.31 & 9.19 & 0.0998 \\
R-squared $=0.9876$, adjusted R-squared $=0.9652$, adequate precision $=16.599$, predicted R-Squared $=0.81$
\end{tabular}
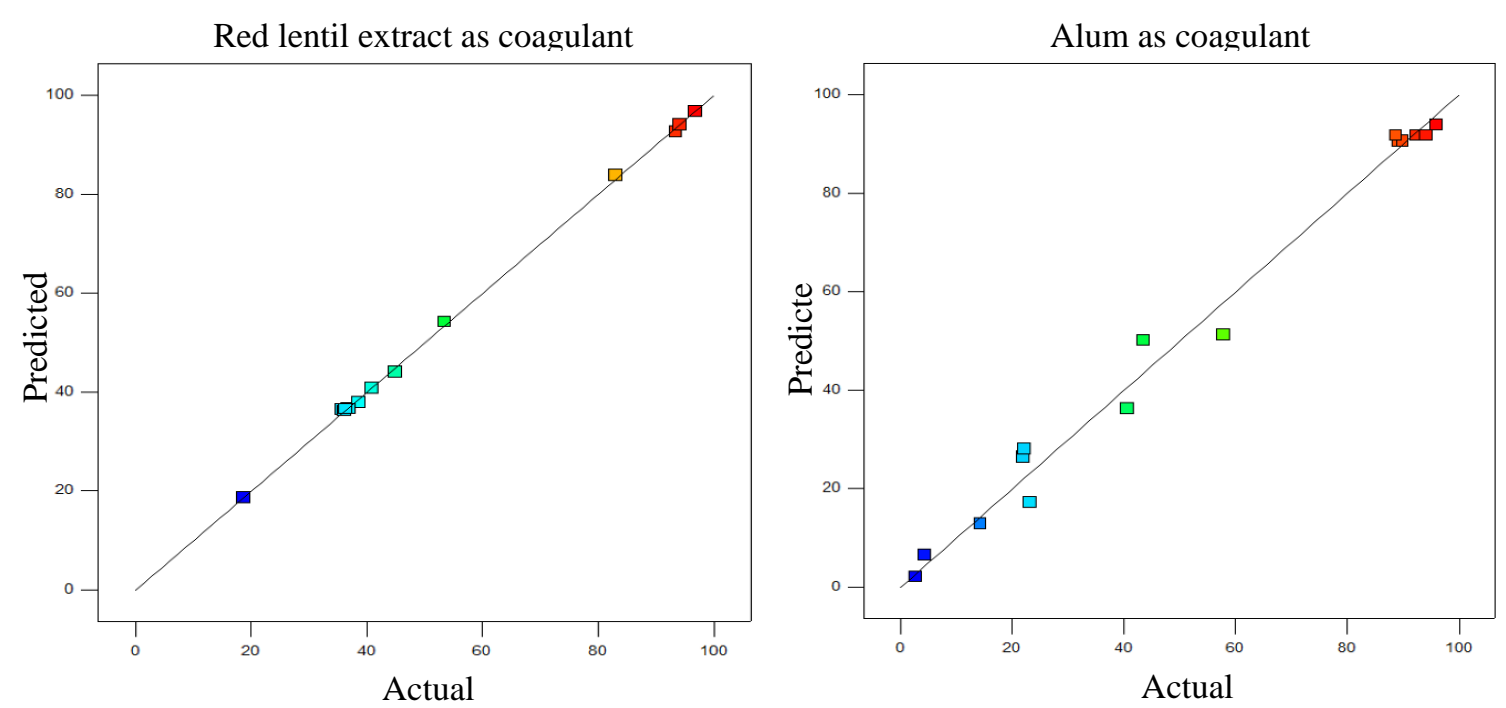

Figure 4. Diagnostic plots: Predicted vs. actual plot for turbidity reduction (red $=$ high turbidity removal, green $=$ medium turbidity reduction and blue $=$ low turbidity reduction). 


\subsection{Effect of Operating Parameters and Their Respective Interactions Using Red Lentil as Coagulant}

Three-dimension surface response of the quadratic model was created using software to evaluate the interaction between the three designed independent variables $(\mathrm{pH}$, the concentration of coagulant and settling time) as shown in Figure 5a-f. For the 3D surface response, the two parameters were systematically varied while the remaining parameter is fixed.
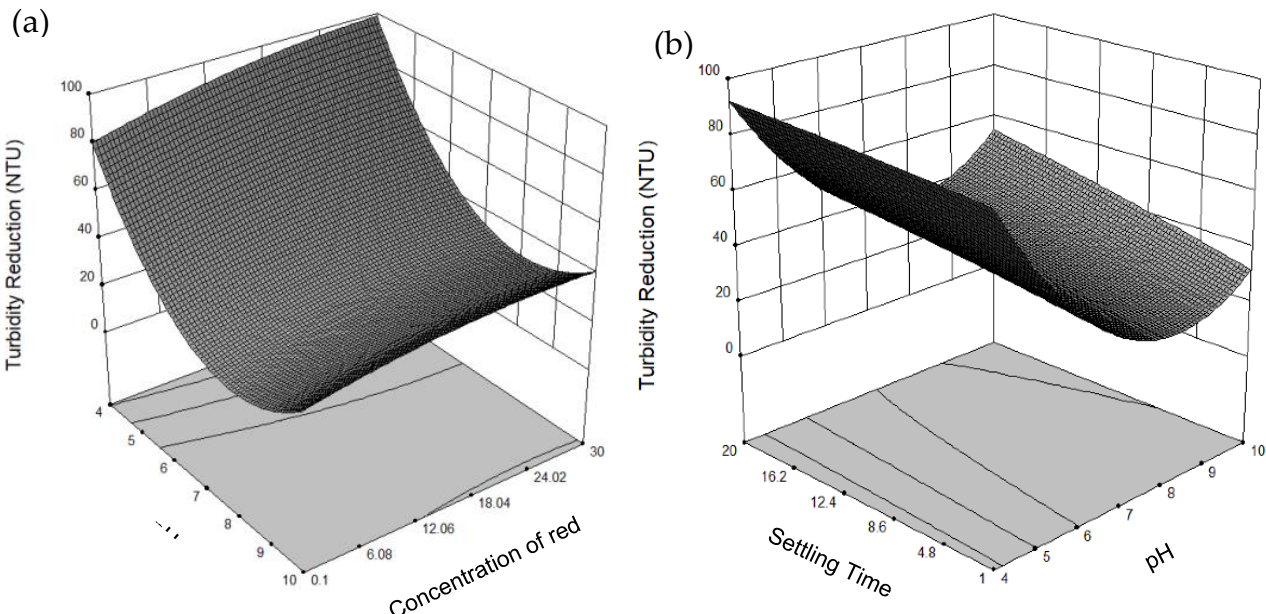

(c)

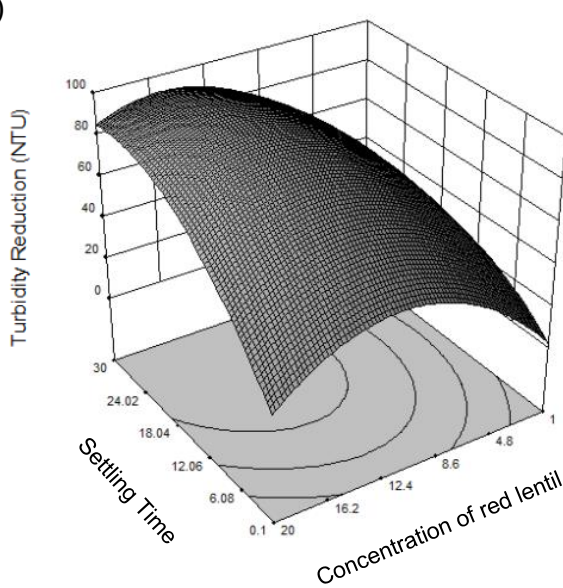

(d)
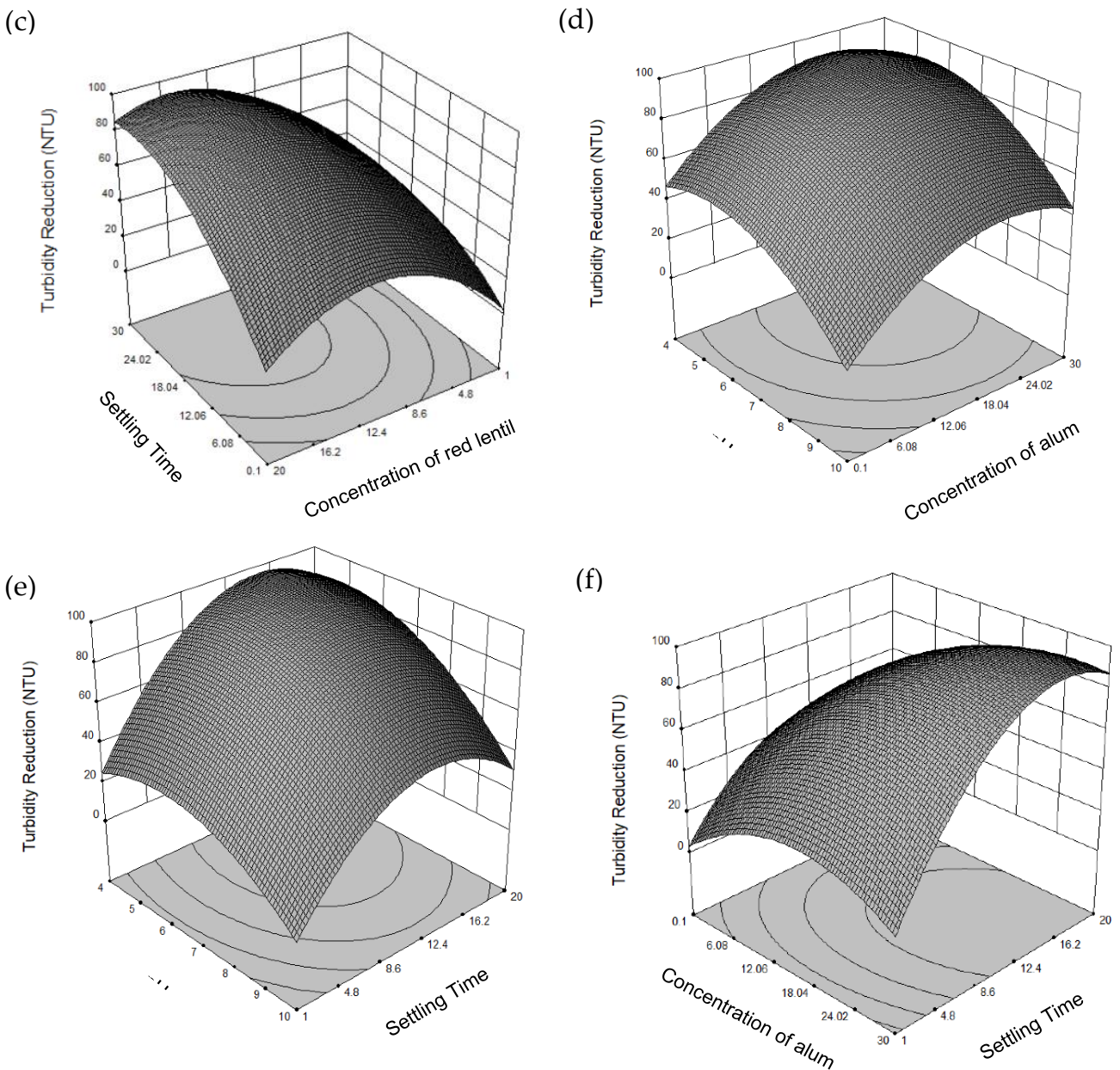

Figure 5. 3D surface plots for turbidity reduction (\%) by using red lentil extract as coagulant and alum as coagulant: (a,d) effect of $\mathrm{pH}$ and concentration of coagulant $(\mathrm{mg} / \mathrm{L}) ;(\mathbf{b}, \mathbf{e})$ effect of settling time (mins) and $\mathrm{pH} ;(\mathbf{c}, \mathbf{f})$ effect of settling time and concentration 


\subsubsection{Effect of $\mathrm{pH}$ and Concentration of Coagulant}

The interaction and relationship between the $\mathrm{pH}$ and concentration of coagulant when settling time is fixed are shown in Figure 5a,d using a 3D representation of the response surface. For lentil as the coagulant (Figure 5a), increased turbidity removal was observed with increasing concentration of red lentil extract and reducing the $\mathrm{pH}$ of the water. Both parameters have strong interaction where the $p$-value was found to be significant (0.0028). Turbidity removal by red lentil extract was found to be highly dependent on the $\mathrm{pH}$ of the water where high turbidity reduction $(>80 \%)$ was achieved at $\mathrm{pH}$ lower than 5. This is attribute to the anionic properties of the red lentil extract where high concentration of hydrogen ions in low $\mathrm{pH}$ water aids the bridging mechanism. The red lentil extract further helps to link the particles through its polymer chain either by physical or chemical attachment. Therefore, an insufficient amount of hydrogen ions in water significantly reduce the efficiency of red lentil extract which clearly shown in Figure 5a. Contrastingly, high turbidity reduction was achieved by alum at the initial $\mathrm{pH}$ range from 5.5-7 which close to the finding by Ghafari et al. [26]. The efficiency of the turbidity reduction is dropped when the $\mathrm{pH}$ is lower than 5.5 as shown in Figure $5 \mathrm{~b}$. This is attribute to the present of sweep coagulation mechanism involved. In $\mathrm{pH}$ lower than 5.5, the charge neutralization was the only mechanism govern the process as the monomeric species, i.e., $\mathrm{Al}^{3+}, \mathrm{Al}(\mathrm{OH})^{2+}$ and $\mathrm{AlOH}^{2 \dagger}$ were predominant in the water [24]. According to the finding by Duan and Gregory [27], sweep coagulation mechanism generally give a higher reduction efficiency than using charge neutralization mechanism alone. Moreover, high concentration of alum significantly impacts the $\mathrm{pH}$ of the water, especially low alkalinity water.

Alum precipitated as hydroxide forms when added to the water which leads to the formation of positive hydrogen ions, and thus reduce the $\mathrm{pH}$ of the water and the turbidity reduction [28]. Besides, a clear peak is observed in Figure $5 b$, indicating that the optimum concentration of the alum was range from $20-28 \mathrm{mg} / \mathrm{L}$.

\subsubsection{Effect of Settling Time and $\mathrm{pH}$}

Figure 5 illustrated the interaction between the settling time and $\mathrm{pH}$ when the concentration of coagulant was kept constant. The surface response indicated that turbidity reduction is significantly impacted by their individual effect and there is some interaction between both parameters. When red lentil extract was used as a coagulant, the settling time parameter showed a trend where it is proportional to the turbidity reduction while a reverse effect was observed when increasing the $\mathrm{pH}$ of the water. The positive hydrogen ions in the water aided the flocculation process which indirectly reduced the required settling time. In the case where alum used as a coagulant, both parameters did not have interaction which evidently by its $p$-value (0.0776) which did not meet the $95 \%$ of confidence level. This was attribute to the less sensitive properties of alum across the $\mathrm{pH}$, thus, did not significantly affect the settling time of the flocs produced. This finding was similar to the finding reported by Shak and $\mathrm{Wu}$ [29], where there is no interaction between the settling time and $\mathrm{pH}$ parameters when alum was used alone as a coagulant.

\subsubsection{Effect of Concentration of Coagulant and Settling Time}

The 3D response surface for turbidity reduction in the function of concentration of alum and settling time is shown in Figure 5 c,f. When red lentil extract was used as coagulant, increase of settling time from 1-20 min aided in turbidity reduction ( $>92 \%)$ until it reaches optimum point (7-9 min). Prolonged settling time after the optimum point did not significantly contribute to the turbidity reduction as the majority of the flocs were settled. A similar trend was observed when alum was used as the coagulant. However, high turbidity reduction was achieved only at settling time from 16-20 min. Coagulation by alum is through charge neutralization mechanism which generally produced a relatively weak and light weighted flocs [30] as compared to coagulation by red lentil extract through bridging and absorption mechanism. Therefore, longer settling time is needed for 
settlement when alum is used as coagulant. Teh et al. [24] reported a similar finding where the optimum settling time of the flocs through rice starch as coagulant was shorter than the alum as the coagulant. Besides, the concentration of the coagulant was significantly affected by the settling time. The increased concentration of coagulant did not significantly improve the turbidity reduction when the settling time was short (1-3 min). After the coagulation-flocculation process, the settling velocity of the flocs was dependent to the size and weight. Therefore, sufficient settling time should be given to ensure the effectiveness of coagulant in turbidity reduction. On the contrary, increase the concentration of coagulant aided in turbidity reduction and reduced the required settling time until it reached an optimum point where increase concentration did not show significant impact to the turbidity removal. This is caused by the insufficient absorption site of the particle surface as they were fully occupied by the excess number of polymers [31]. The turbidity removal efficiency was enhanced by adopting a higher coagulant dosage, until it reached optimal point [32].

\subsection{Multiple Responses Optimization for Turbidity Reduction}

The regression equation of the turbidity reduction for red lentil extract and alum as coagulant were illustrated as follows:

$$
\begin{aligned}
& \text { Turbidity Reduction ( } \\
& \qquad \begin{aligned}
& \text { red lentil extract) } \\
&=36.58-23.94 X_{1}+4.06 X_{2}+4.71 X_{3}-2.43 X_{1} X_{2} \\
&+4.02 X_{1} X_{3}-4.89 X_{2} X_{3}+33.47 X_{1}^{2}-3.65 X_{2}^{2} \\
&-0.63 X_{3}^{2}
\end{aligned}
\end{aligned}
$$

where $X_{1}=\mathrm{pH} ; X_{2}=$ concentration of red lentil extract; $X_{3}=$ settling time

$$
\begin{aligned}
\text { Turbidity Reduction } & \text { (alum) } \\
& =91.77-19.70 Y_{1}+19.12 Y_{2}+24.57 Y_{3} \\
& -0.50 Y_{1} Y_{2}-7.50 Y_{1} Y_{3}+13.77 Y_{2} Y_{3}-19.07 Y_{1}^{2} \\
& -21.49 Y_{2}^{2}-33.86 Y_{3}^{2}
\end{aligned}
$$

where $Y_{1}=\mathrm{pH} ; Y_{2}=$ concentration of alum; $Y_{3}=$ settling time.

The coefficients of the individual parameter, i.e., $X_{1}$ and two parameters, i.e., $X_{1} X_{2}$, represent the individual effect of the particular parameter and the interaction between the parameters, respectively. In both regression equations, the positive sign of the coefficient reveals the synergistic effect, whereas the negative sign represents the antagonistic effect. The optimal conditions of the operating parameters and turbidity reduction for red lentil extract as coagulant and alum as coagulant were determined by using the equation. When red lentil extract was used as coagulant, the optimum conditions for $\mathrm{pH}$, coagulant concentration and settling time were $4.0,26.3 \mathrm{mg} / \mathrm{L}$, and 3 minutes to achieved $98.68 \%$ of turbidity reduction. On the contrary, the optimum conditions for $\mathrm{pH}$, coagulant concentration and settling time when alum used as coagulant were $6.8,28.5 \mathrm{mg} / \mathrm{L}$, and 19 minutes to achieve $98.37 \%$ turbidity reduction. As compared to alum, red lentil extract required $84 \%$ shorter settling time and highly effective in acidic water. For acidic wastewater $(\mathrm{pH} 4)$, the maximum turbidity reduction achieved by alum was only $95.42 \%$ turbidity with $26 \mathrm{mg} / \mathrm{L}$ concentration of alum and $10 \mathrm{~min}$ settling time. Therefore, it can be concluded that red lentils extract outperformed alum for turbidity reduction in acidic turbid water. The result reveals the possibility of red lentil extract as an effective and eco-friendly coagulant for acidic wastewater such as effluent from fertilizer industries [33] and palm oil mill (POME) [29], which are two major environmental issues recently.

\subsection{Validation of the Designed Model}

To validate the designed model, total of six confirmation experiments were conducted. The experiment runs were randomly chosen from the range of high, medium and low turbidity reduction from each designed model. Their respective value of $\mathrm{pH}$, concentration of coagulant and settling time 
are illustrated in Table 5. The validation results proved that the predicted value from the BBD models was accurate and in good agreement with all the actual experimental values achieved within a $95 \%$ confidence interval.

Table 5. Confirmation experiment runs.

\begin{tabular}{|c|c|c|c|c|c|}
\hline \multirow{2}{*}{$\mathrm{pH}$} & \multirow{2}{*}{$\begin{array}{l}\text { Concentration of Alum, } \\
(\mathrm{mg} / \mathrm{L})\end{array}$} & \multirow{2}{*}{$\begin{array}{l}\text { Settling Time, } \\
\text { (min) }\end{array}$} & \multicolumn{3}{|c|}{ Turbidity Reduction (\%) } \\
\hline & & & Predicted $^{\mathrm{a}}$ & Actual ${ }^{b}$ & Different \\
\hline \multicolumn{6}{|c|}{ Red lentil extract as coagulant } \\
\hline 4.0 & 26.3 & 3.0 & 98.68 & 98.87 & 0.18 \\
\hline 5.8 & 14.5 & 16.0 & 53.40 & 51.32 & 2.08 \\
\hline 9.3 & 10.0 & 3.7 & 24.94 & 26.42 & 1.48 \\
\hline \multicolumn{6}{|c|}{ Alum as coagulant } \\
\hline 6.0 & 24.6 & 10 & 98.48 & 97.64 & 0.84 \\
\hline 4.8 & 23.7 & 3.5 & 53.59 & 50.60 & 2.99 \\
\hline 9.9 & 15.87 & 2.3 & 13.45 & 16.25 & 2.80 \\
\hline
\end{tabular}

a Predicted using BBD response surface quadratic model. ${ }^{b}$ Average value from triplicate values of the experiment runs.

\subsection{Evaluation of Sludge/Flocs Produced}

Apart from the efficiency in turbidity reduction, sludge production after the treatment process was considered in this study as it significantly affects the economic feasibility of lentil extract. As shown in Figure 6, the treatment process using red lentil extract produced an average $8.1 \mathrm{~mL} / \mathrm{L}$ of sludge while treatment using alum produce an average $9.6 \mathrm{~mL} / \mathrm{L}$ of sludge. This result further evinced the possibility of red lentil extract as coagulant as it reduced up to $15.6 \%$ of the sludge produced. Ndabigengesere and Narasiah [34] found a similar result which the use of natural coagulant (Moringa oleifera) generated less sludge as compared to alum. The larger sludge volume generated from the treatment using alum was attributed to the production of aluminum hydroxide as a precipitate [34]. Moreover, the sludge produced using alum was found to be less compact as illustrated in Figure 7, which led to a higher amount of the sludge. Generally, different coagulants have different coagulating and flocculation mechanisms which produce different amount and properties of sludge. The result obtained reveals the mechanisms involved in the treatment by red lentil extract helps to produce a more compact sludge. The details of the mechanisms involved in red lentil extract is discussed later.

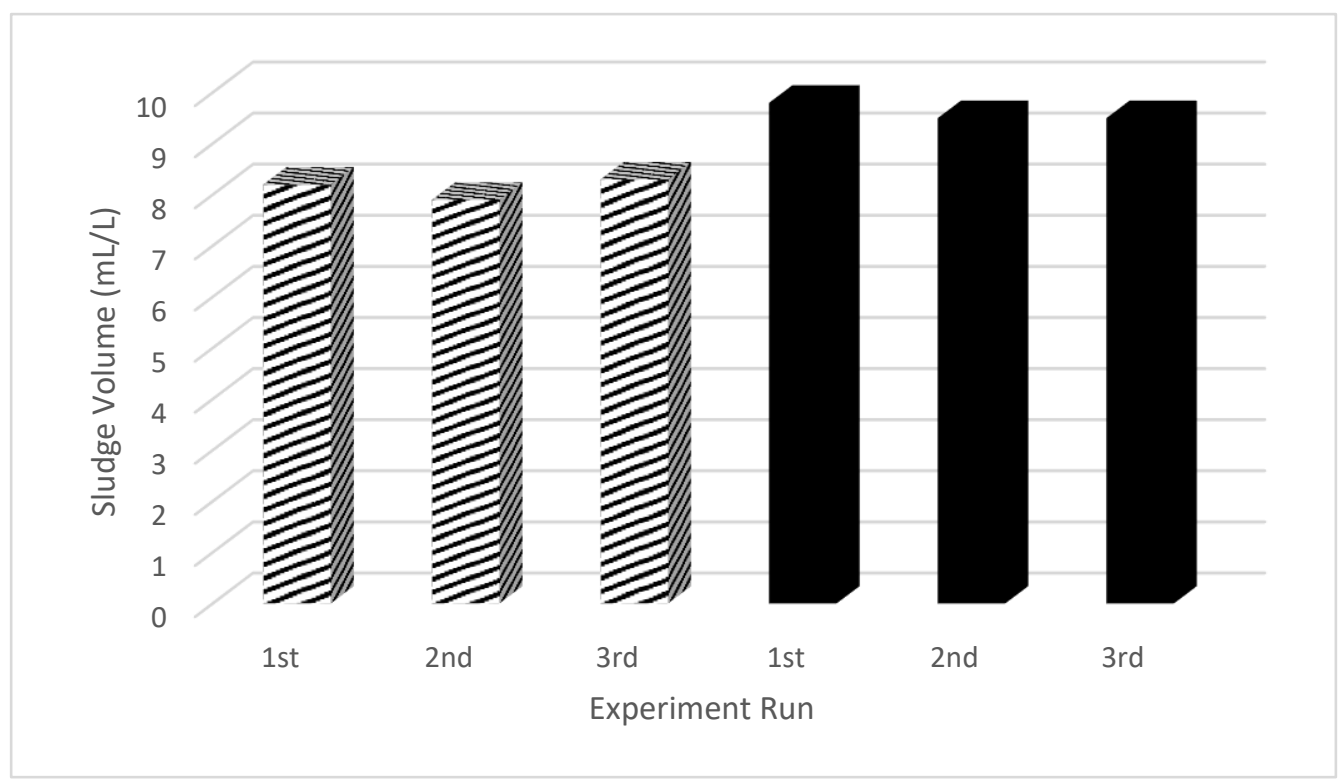

Figure 6. Volume of sludge produced after the treatment process. 


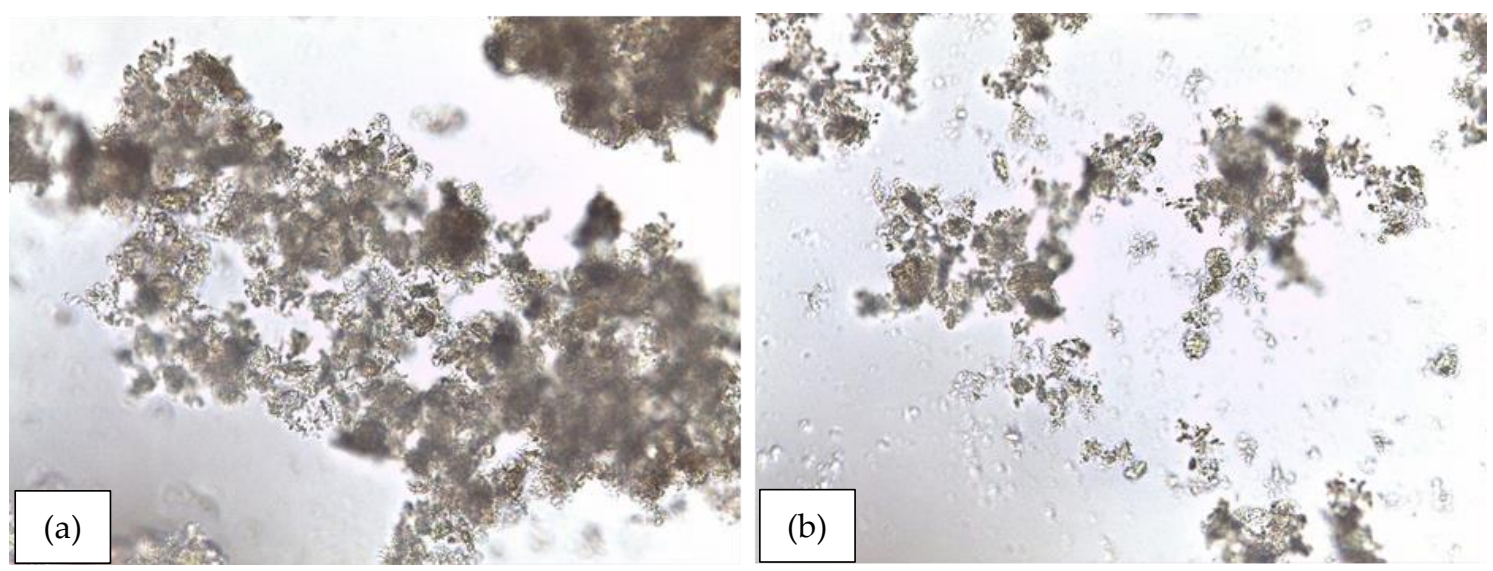

Figure 7. The flocs/sludge produced under 40× Magnification when (a) red lentil extract, (b) alum used as coagulant.

The SVI value is generally used to determine the settleability characteristics of the sludge/flocs produced. In this study, the SVI values were calculated at the optimal dose of red lentil extract and alum at $\mathrm{pH}$ 4. The SVI value of the flocs after the treatment using red lentil extract and alum were $7.39 \mathrm{~mL} / \mathrm{g}$ and $8.72 \mathrm{~mL} / \mathrm{g}$, respectively. The lower SVI value of the flocs produced by red lentil extract revealed its ability to produce flocs with better settling characteristics as compared to alum.

\subsection{Economic Feasibility Analysis of Lentil Extracts as Coagulant}

Globally, economic is one of the critical aspects to evaluate the feasibility of material for a certain application. For the coagulation-flocculation process, the major costs are made up from two aspects, chemical and sludge management cost. Therefore, the economic interest to utilize red lentils as the coagulant in industrial turbidity reduction were evaluated based on these two aspects. The material costs of red lentil extract and alum $[24,35]$ were calculated based on the optimum concentration found in this study and tabulated in Table 6 . Red lentil extract was found to be more economical treatment option with a chemical cost of $\$ 0.0079$ as compared to alum with $\$ 0.0112$ per cubic meter of wastewater treated. The result reveals the use of red lentil extract reduced up to $29.42 \%$ material cost of the treatment, which evinced the high feasibility of red lentil extract as the coagulant for turbidity reduction in acidic wastewater treatment.

Table 6. Cost of red lentil extract and alum in turbidity reduction.

\begin{tabular}{|c|c|c|c|}
\hline Coagulant & Unit Price $(\$ / \mathbf{k g})$ & $\begin{array}{l}\text { Optimum Concentration, } \\
\times 10^{-3}\left(\mathrm{~kg} / \mathrm{m}^{3}\right)\end{array}$ & $\begin{array}{l}\text { Total Material Cost, } \\
\quad \times 10^{-3}\left(\$ / \mathrm{m}^{3}\right)\end{array}$ \\
\hline Red lentil extract & 0.30 & 26.3 & 7.89 \\
\hline Alum & 0.43 & 26 & 11.18 \\
\hline
\end{tabular}

The sludge management of using red lentil extract and alum as coagulant were evaluated as it generally accounts up to $50 \%$ of the total wastewater treatment cost. According to the U.S. Environmental Protection Agency, the management cost of sludge is range from \$35-38 per dry ton. As discussed earlier, the sludge production volume for red lentil extract as coagulant was $15.6 \%$ lower which could save up to $\$ 5.9$ per ton of the sludge produced. Besides, the treatment using alum generated aluminum-based sludge, which required higher cost and special treatment in certain countries, i.e., Malaysia classified aluminum-based sludge as Scheduled Waste (SW204) [36]. Contrastingly, the sludge generated by using red lentil extract is biodegradable organics which may reuse as a fertilizer. Therefore, utilizing red lentil extracts as the coagulant for turbidity reduction 
in acid wastewater treatment offer few great advantages such as material and sludge disposal cost reduction and sustainable development through beneficial reuse of the waste product.

\subsection{Proposed Mechanism for Red Lentil Extract}

The preliminary study of the flocculating ability of different lentil extracts suggested that the lentils with higher amount of protein and amylose exhibit a higher efficiency in turbidity reduction. Therefore, the active agents of the lentil extract were postulated to be water-soluble protein which similar to Moringa oleifera and amylose from the starch.

Generally, the suspended particles in the water absorbed into the polymer through electrostatic force by the opposite charge polymer, hydrogen bonding and hydrophobic properties of the polymer that contain non-polar groups i.e., $\mathrm{CH}_{2}$. The proposed mechanism coagulation-flocculation by red lentil extract during the optimum condition ( $\mathrm{pH} 4$ and $26.3 \mathrm{mg} / \mathrm{L}$ concentration of red lentil extract) was adsorption facilitated by interparticle bridging mechanism as illustrated in Figure 8. The proposed bridging mechanism was supported by the behavior of the turbidity removal curve by the red lentil extract (Figure $5 \mathrm{c}$ ) where the turbidity reduction reduced after the optimal concentration. In the bridging mechanism, a sufficient number of unoccupied surfaces on the particle is needed for the polymer bridging process. The excessive polymers on the surface particle inhibit the coagulation-flocculation process. This phenomenon is known as steric stabilization [37]. The proposed mechanism was further supported by the chemical compositions of red lentil extract. The divalent ions that present in lentil extract, i.e., $\mathrm{Ca}^{+2}$, aided in the complex formation of the coagulation-flocculation process through a synergistic effect. The compact structure of flocs formed by using red lentil extract as the coagulant (Figure 7a) also supported the proposed adsorption and bridging mechanism.

\section{Fast Mixing}

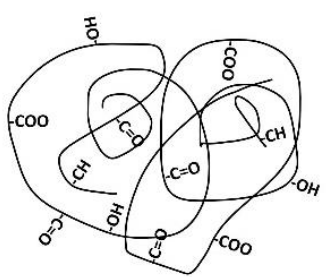

Red lentil extract

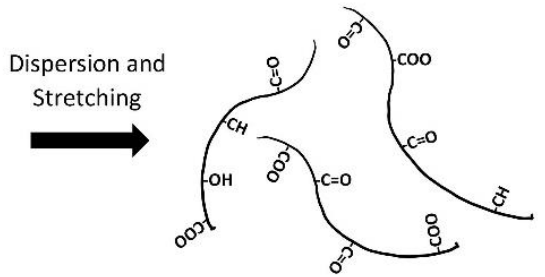

Red lentil extract

Slow Mixing

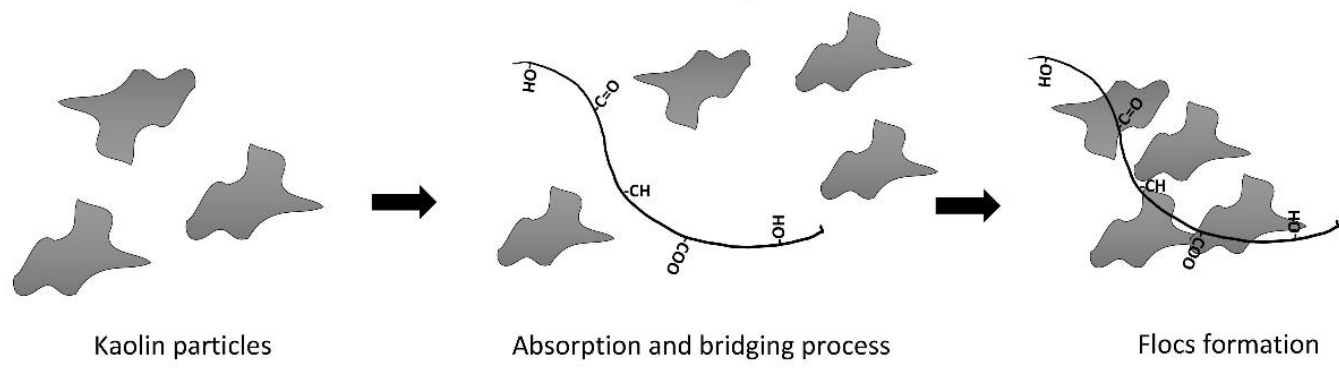

Figure 8. Proposed mechanism for red lentil extract as coagulant.

\section{Conclusions}

This study has successfully examined the feasibility of the red lentil extract as the coagulant for turbidity reduction as a coagulant. There are a few significant conclusions that can be drawn from this study. 
- $\quad$ Red lentil extract has the highest turbidity reduction efficiency, followed by brown lentils and green lentil extract.

- The main active compounds of red lentil extract were postulated to be the soluble protein and the amylose. Besides, the coagulation-flocculation mechanism utilizing red lentil extract as a coagulant was found to be adsorption and facilitated by bridging.

- The high correlation of the designed model revealed the suitability of the second-order polynomial model using BBD as an optimization tool to optimize the operating parameters for turbidity reduction. The utilization of red lentil extract as coagulation can be achieved up to $98.87 \%$ of turbidity reduction and the optimal conditions for $\mathrm{pH}$, concentration of coagulant and settling time were $4,26.3 \mathrm{mg} / \mathrm{L}$, and $3 \mathrm{~min}$. This promising efficiency was comparable to those acquired by using alum as the coagulant.

- The red lentil extract was found to be more environmentally friendly approached as it generated $15.6 \%$ lower sludge as compared to alum as coagulation and helped to reduce the sludge management cost for the wastewater treatment. Besides, it produced flocs with better settling characteristic (based on SVI) as compared to alum.

Therefore, it can be concluded that the red lentil extract was a promising and effective natural coagulant for acidic wastewater. It can be an alternative to chemical coagulants and a sustainable choice for turbidity reduction in the treatment of acidic wastewater. Besides, the characterization and optimization study of the lentil extract as the natural coagulant is expected to provide valuable information for other applications in environmental and related fields.

Author Contributions: Conceptualization, S.-C.C. and Y.-C.H.; Data curation, S.-C.C.; Formal analysis, S.-C.C., Y.-C.H. and F.-K.C.; Funding acquisition, Y.-C.H. and M.A.M.; Methodology, S.-C.C.; Resources, Y.-C.H., F.-K.C., W.S. and M.A.M.; Software, S.-C.C.; Supervision, Y.-C.H., F.-K.C. and M.A.M.; Validation, Y.-C.H., F.-K.C., W.S. and M.A.M.; Visualization, Y.-C.H. and W.S.; Writing—original draft, S.-C.C.; Writing—review \& editing, Y.-C.H., F.-K.C., W.S. and M.A.M.

Funding: Financial support through the funding of YUTP grant (0153AA-E34) from PETRONAS and iRMC Bold2025 (Grant Code: RJO 1043 6494) from Universiti Tenaga Nasional, Malaysia are acknowledged.

Acknowledgments: The authors would like to acknowledge Mdm. Norhayama Bt Ramli for technical assistance in Environmental Laboratory and Universiti Teknologi PETRONAS for providing necessary facilities.

Conflicts of Interest: The authors declare no conflict of interest.

\section{References}

1. Fermino, L.; Pedrangelo, A.; Silva, P.; Azevedo, R.; Yamaguchi, N.; Ribeiro, R. Water Treatment with Conventional and Alternative Coagulants. Chem. Eng. Trans. 2017, 57, 1189-1194.

2. Harfouchi, H.; Hank, D.; Hellal, A. Response surface methodology for the elimination of humic substances from water by coagulation using powdered Saddled sea bream scale as coagulant-aid. Process Saf. Environ. Prot. 2016, 99, 216-226. [CrossRef]

3. Roy, F.; Boye, J.; Simpson, B. Bioactive proteins and peptides in pulse crops: Pea, chickpea and lentil. Food Res. Int. 2010, 43, 432-442. [CrossRef]

4. Jood, S.; Bishnoi, S.; Sharma, A. Chemical analysis and physico-chemical properties of chickpea and lentil cultivars. Food/Nahr. 1998, 42, 71-74. [CrossRef]

5. Canada, A.A.-F. Lentils: Situation and outlook. Available online: http://www.agr.gc.ca/ (accessed on 26 April 2019).

6. Schulz, C.R.; Okun, D.A. Treating surface waters for communities in developing countries. J. Am. Water Work. Assoc. 1983, 75, 212-219. [CrossRef]

7. Ordaz-Díaz, L.A.; Valle-Cervantes, S.; Rodríguez-Rosales, J.; Bailón-Salas, A.M.; Madrid-Del Palacio, M.; Torres-Fraga, K.; Luis, A. Zeta Potential as a Tool to Evaluate the Optimum Performance of a Coagulationflocculation Process for Wastewater Internal Treatment for Recirculation in the Pulp and Paper Process. BioResources 2017, 12, 5953-5969. [CrossRef]

8. Roy, A.; Bhattacharya, J. Nanotechnology in Industrial Wastewater Treatment; IWA Publishing: London, UK, 2015. 
9. Association, A.P.H.; Association, A.W.W.; Federation, W.P.C.; Federation, W.E. Standard Methods for the Examination of Water and Wastewater; American Public Health Association: Washington, DC, USA, 1915; Volume 2.

10. Zarei, M.; Niaei, A.; Salari, D.; Khataee, A. Application of response surface methodology for optimization of peroxi-coagulation of textile dye solution using carbon nanotube-PTFE cathode. J. Hazard. Mater. 2010, 173, 544-551. [CrossRef] [PubMed]

11. Choudhary, M.; Ray, M.B.; Neogi, S. Evaluation of the potential application of cactus (Opuntia ficus-indica) as a bio-coagulant for pre-treatment of oil sands process-affected water. Sep. Purif. Technol. 2019, 209, 714-724. [CrossRef]

12. Zheng, H.; Sun, Y.; Guo, J.; Li, F.; Fan, W.; Liao, Y.; Guan, Q. Characterization and evaluation of dewatering properties of PADB, a highly efficient cationic flocculant. Ind. Eng. Chem. Res. 2014, 53, 2572-2582. [CrossRef]

13. Ma, J.; Fu, K.; Shi, J.; Sun, Y.; Zhang, X.; Ding, L. Ultraviolet-assisted synthesis of polyacrylamide-grafted chitosan nanoparticles and flocculation performance. Carbohydr. Polym. 2016, 151, 565-575. [CrossRef]

14. Ahmad, R.; Haseeb, $\mathrm{S}$. Absorptive removal of $\mathrm{Pb} 2+, \mathrm{Cu} 2+$ and $\mathrm{Ni} 2+$ from the aqueous solution by using groundnut husk modified with Guar Gum (GG): Kinetic and thermodynamic studies. Groundw. Sustain. Dev. 2015, 1, 41-49. [CrossRef]

15. Agunbiade, M.; Pohl, C.; Ashafa, O. Bioflocculant production from Streptomyces platensis and its potential for river and waste water treatment. Braz. J. Microbiol. 2018, 1-10. [CrossRef] [PubMed]

16. Aziz, H.; Rahim, N.; Ramli, S.; Alazaiza, M.; Omar, F.; Hung, Y.-T. Potential Use of Dimocarpus longan Seeds as a Flocculant in Landfill Leachate Treatment. Water 2018, 10, 1672. [CrossRef]

17. Benalia, A.; Derbal, K.; Panico, A.; Pirozzi, F. Use of Acorn Leaves as a natural coagulant in a drinking water treatment plant. Water 2019, 11, 57. [CrossRef]

18. Shak, K.P.Y.; Wu, T.Y. Coagulation-flocculation treatment of high-strength agro-industrial wastewater using natural Cassia obtusifolia seed gum: treatment efficiencies and flocs characterization. Chem. Eng. J. 2014, 256, 293-305. [CrossRef]

19. Kakoi, B.; Kaluli, J.W.; Ndiba, P.; Thiong'o, G. Banana pith as a natural coagulant for polluted river water. Ecol. Eng. 2016, 95, 699-705. [CrossRef]

20. Ghori, M.U.; Mohammad, M.A.; Rudrangi, S.R.S.; Fleming, L.T.; Merchant, H.A.; Smith, A.M.; Conway, B.R. Impact of purification on physicochemical, surface and functional properties of okra biopolymer. Food Hydrocoll. 2017, 71, 311-320. [CrossRef]

21. Chung, H.-J.; Liu, Q.; Hoover, R.; Warkentin, T.D.; Vandenberg, B. In vitro starch digestibility, expected glycemic index, and thermal and pasting properties of flours from pea, lentil and chickpea cultivars. Food Chem. 2008, 111, 316-321. [CrossRef]

22. Ma, Z.; Boye, J.I.; Simpson, B.K.; Prasher, S.O.; Monpetit, D.; Malcolmson, L. Thermal processing effects on the functional properties and microstructure of lentil, chickpea, and pea flours. Food Res. Int. 2011, 44, 2534-2544. [CrossRef]

23. Okumus, B.N.; Tacer-Caba, Z.; Kahraman, K.; Nilufer-Erdil, D. Resistant starch type V formation in brown lentil (Lens culinaris Medikus) starch with different lipids/fatty acids. Food Chem. 2018, 240, 550-558. [CrossRef]

24. Teh, C.Y.; Wu, T.Y.; Juan, J.C. Optimization of agro-industrial wastewater treatment using unmodified rice starch as a natural coagulant. Ind. Crop. Prod. 2014, 56, 17-26. [CrossRef]

25. Ahmad, A.; Wong, S.; Teng, T.; Zuhairi, A. Optimization of coagulation-flocculation process for pulp and paper mill effluent by response surface methodological analysis. J. Hazard. Mater. 2007, 145, 162-168. [CrossRef]

26. Ghafari, S.; Aziz, H.A.; Bashir, M.J. The use of poly-aluminum chloride and alum for the treatment of partially stabilized leachate: A comparative study. Desalination 2010, 257, 110-116. [CrossRef]

27. Duan, J.; Gregory, J. Coagulation by hydrolysing metal salts. Adv. Colloid Interface Sci. 2003, 100, 475-502. [CrossRef]

28. Banu, R.; Do, K.; Yeom, I. Phosphorus removal in low alkalinity secondary effluent using alum. Int. J. Environ. Sci. Technol. 2008, 5, 93-98. [CrossRef]

29. Shak, K.P.Y.; Wu, T.Y. Optimized use of alum together with unmodified Cassia obtusifolia seed gum as a coagulant aid in treatment of palm oil mill effluent under natural $\mathrm{pH}$ of wastewater. Ind. Crop. Prod. 2015, 76, 1169-1178. [CrossRef] 
30. Sanghi, R.; Bhatttacharya, B.; Singh, V. Cassia angustifolia seed gum as an effective natural coagulant for decolourisation of dye solutions. Green Chem. 2002, 4, 252-254. [CrossRef]

31. Bolto, B.; Gregory, J. Organic polyelectrolytes in water treatment. Water Res. 2007, 41, 2301-2324. [CrossRef]

32. Wu, P.; Jiang, L.Y.; He, Z.; Song, Y. Treatment of metallurgical industry wastewater for organic contaminant removal in China: status, challenges, and perspectives. Environ. Sci. Water Res. Technol. 2017, 3, 1015-1031. [CrossRef]

33. Al-Harahsheh, M.; Batiha, M.; Kraishan, S.; Al-Zoubi, H. Precipitation treatment of effluent acidic wastewater from phosphate-containing fertilizer industry: characterization of solid and liquid products. Sep. Purif. Technol. 2014, 123, 190-199. [CrossRef]

34. Ndabigengesere, A.; Narasiah, K.S. Quality of water treated by coagulation using Moringa oleifera seeds. Water Res. 1998, 32, 781-791. [CrossRef]

35. Haydar, S.; Aziz, J.A. Coagulation-flocculation studies of tannery wastewater using combination of alum with cationic and anionic polymers. J. Hazard. Mater. 2009, 168, 1035-1040. [CrossRef]

36. Choy, S.Y.; Prasad, K.N.; Wu, T.Y.; Raghunandan, M.E.; Ramanan, R.N. Performance of conventional starches as natural coagulants for turbidity removal. Ecol. Eng. 2016, 94, 352-364. [CrossRef]

37. Mishra, S.; Mukul, A.; Sen, G.; Jha, U. Microwave assisted synthesis of polyacrylamide grafted starch (St-g-PAM) and its applicability as flocculant for water treatment. Int. J. Biol. Macromol. 2011, 48, 106-111. [CrossRef]

(C) 2019 by the authors. Licensee MDPI, Basel, Switzerland. This article is an open access article distributed under the terms and conditions of the Creative Commons Attribution (CC BY) license (http://creativecommons.org/licenses/by/4.0/). 